\title{
Carpaccio, Saint Stephen, and the Topography of Jerusalem.
}

\author{
David R. Marshall
}

The relationship between Carpaccio's paintings and the woodcuts by Erhard Reuwich in Bernhard von Breydenbach's Peregrinationes in Terram Sanctam' has engaged the interest of Carpaccio scholars since it was first observed by Sidney Colvin in 1897.2 Ludwig and Molmenti' regarded the woodcuts as an important source for Carpaccio, and, among many instances, detected borrowings from Reuwich's large Vtew of Jerusalem and the Holy Land (Fig. 3) - the most important of Reuwich's woodcuts - in the Sermon of Saint Stepher and the Stoning of Saint Stephen (Figs. 1-2), which, together with the Saint Stephen and His Six Companions Ordained Deacons by Saint Peter, the Disputation of Saint Stephen, and the lost Trial of Saint Stephen, make up the cycle of the life of Saint Stephen painted for the Scuola di Sto. Stefano between 1511 and $1520,{ }^{4}$ In the Sermon (Fig, 1), for example, there is a temple corresponding to the Dome of the Rock, and the Church of the Holy Sepulchre is visible beyond it. But could not Carpaccio have acquired such topographical information from other sources, perhaps even his own studies from life? And what is the source of the exotic elements that do not derive from Reuwich? These and other considerations have meant that Carpaccio's dependence on Reuwich has not gone unchallenged, although it is generally accepted to a greater or lesser extent." By reexamining the relationship between Carpaccio's Saint Stephen cycle and Reuwich's woodcuts, it is possible not only to confirm that Carpaccio did, indeed, draw on Reuwich's woodcuts and had no further sources of information about Jerusalem, but also to throw some light on the way in which Carpaccio created his settings. Such a reexamination involves not only comparisons between Carpaccio and Reuwich, but a consideration of the other sources upon which they drew.

1

In the Sermon the dependence of Carpaccio on Reuwich is most obvious. The Church of the Holy Sepulchre is rendered almost exactly as in the View of Jerusalem and another woodcut devoted to the church alone: the campanile is shown obliquely, the right side shaded; the various domes are shown in the same relative positions; the fragmentary cupola over the main dome is present, and the buildings that enclose the courtyard are much the same and disposed at the same angle. The fenestration of the façade has been changed by the addition of small windows on the left to balance those on the right in the woodcuts, but not in the interests of greater accuracy, as the actual building did not possess them. Instead, this change is indicative of a process of clarification and simplification through which Carpaccio converted the often ambiguous forms of the woodcuts into structures compatible with his own way of rendering buildings.

The resemblance of the temple behind Saint Stephen in form and location to the Dome of the Rock is clear, but Gilles de la Tourette observed that an open parapet such as Carpaccio represents would have been visible before it

\footnotetext{
1 First published Mainz, 1486. For a full account of the various editions, see H. W. Davies, Bernhand von Breydembach and His Joumey to the Holy Land 1483-64, London, 1911. See also Bernhard von Breydenbach, Dis Reise ins Heilige Land. Ein Reisebericht aus dem Jahre 1063, trans. and intro. E. Geck. Wiesbaden, 1961 and H. Kunze, Geschichte der Buch. diustration in Deurschlard des 15 th. Leiprig, 1975, 332-43.

25. Colvin, "Uber einize Zeichnungen des Carpaccio in England," lahr. buch der Kanizlichen Prewssischen Kurstsarumblungen, xvin, 1897. 193204

${ }^{3}$ 185-86 and paseim.

- Paris, Louvre No, 12110; Stuttgart, Staatsgalerie No. 311; Berlin, Ehemals Staatliche Museen, Gemaldegalerie No. 23; Milan. Beera (No. 170). There is an old copy of the modbllo for the Trial in the Uifizi (No. 1687 which is of little topographical interest.

sTe Tietres proposed that Carpaccio and Reuwich both used drawirgs by Gentile Bellini. who in $1479-80$ made a joumey to Constantinople (pp. 6.3ff and 1.38ff. Their argument has little validity in the case of the setting of the Saint Stephen cycle, for there is no evidence that Gentile ever went to Jerusalem isee L. Thuasne. Gentile Bellini and 5uhtan Mohammed II.
}

\begin{abstract}
Paris, 1885, and H. F. Collins, 'Gentile Bellini: A Monograph and a Catalogue of His Works," Ph.D. diss., University of Pittsburgh, 1970, 12-20). The question of whether Bellini could have visited Damascus or Alex. andria (and, therefore, perhaps Jerusalem) on the retura journey has been considered by C. C. Roulllard, who finds it unlikely f"A Reconsideration of La Riception de I'Ambassadeur Domenico Trevisano au Caire. Ecole de Gentile Bellind,"' Gazette des beaux-arts, ser. 6, Looxt, 1973, 297-304). In fact, Jerusalem was probably more accessible from Venice, which had a vigorous pilgrim trade, than from Constantinople, which was controlled by the Ottoman Turks and not by the Mamelukes who ruled Jerusalem. Ficceo, 29ff, raised the possibility that Carpaccio himself made a journey to the East, and there drew the same subjects is Reuwich, but although this is a posstbility, dires eviderce for such a jeurney is lacking. The only documentary widence in support of it is a passage in the 1590 edition of Cesare Vecellio's Degli habiti antichi e modemi which mentions "un certo Vittorio Scarpe" summoned to the court of the Sultan. Whether this refers to Carpaccio, and whether it is a credible report. are matters of doubs (see Tietze and Twetze-Conrat, 141-42). Recently Muraro (Vittore Car. paccio, idisegni, Forence, 1977, 52), has expressed a belief in the eastern journey, but without supplying new evidence. For a full account, see Zampetti. 511-26: also Luts, 20.
\end{abstract}


was hidden by the faience covering added during Suleiman the Magnificent's restoration work in 1552, and argued that Carpaccio must therefore have had other sources. ${ }^{\circ}$ Creswell has since shown, however, that the parapet has always been solid.? Carpaccio could, indeed, have easily interpreted Reuwich's rendering as indicating a parapet of the type he represents. And while Carpaccio's building seems at first to show a dome closer in form to that of the actual building. it has an incipient reflex curve (just visible at the edge of the canvas) like Reuwich's onion dome. When Carpaccio departs from Reuwich's temple, the differences in detail, such as the parapet and the tympanum over the door, may be explained by reference to the same process of simplification and translation into his own system of forms as observed with the Church of the Holy Sepulchre. The greater vertical emphasis may be explained by compositional necessity. It is also significant that, as has often been observed, this building is closely related to a number of representations of ideal churches, particularly those of Umbrian origin, such as the temples in Perugino's Delivery of the Keys and Raphael's Sposalizio." This is as it should be, for the ideal centrally planned church of the Renaissance was an attempt to apply the same divinely inspired proportions that were used by Solomon when he constructed his Temple. At this time the Dome of the Rock was sometimes thought to be Solomon's Temple, and it is labeled Templum Salomonis by Reuwich. By bringing his representation into conformity with Renaissance ideals, Carpaccio was at the same time approaching more nearly the true appearance of Solomon's Temple. ${ }^{17}$

Only the Sermon and the Stoning (Fig. 2) have settings that recall Jerusalem specifically, but the other paintings have fantastic elements for which Eastern origins have been

$\circ$ De La Tourette, 139-40. He argues against Carpaccio having traveled to the Orient himself.

7 K.A.C. Creswell, Early Muslim Archirecture, 2nd ed. Oxford, 1960, 69-50 and $\mathrm{pl}, 2 \mathrm{~b}$.

$5 \mathrm{Cf}$. De La Tourette, 139.40 .

Zampetti, 52Jif.

to Vatican, Sistine Chapel- Brera, Milan.

"I R. Wittkower, Architectural Principles in the Ase of Humenism, London, 1973, 102ff, and Appendix L. 155-57. For the Dome of the Rock as the Temple of Solomon, see C.H. Krinsky, "Representations of the Temple of Jerusalem before 1500," Joumal of the Warbarg and Courtauld Institutes, $\times \times \times 11,1970,1-20$

12 Fiocco, 45, sees it as evidence of Carpaccio's eastern joumey. Ludwie and Molmenti, 186, trace it to the pyramids in Reuwich's print, but although these bave the curved sides of Carpaccio's pyramid they are too impoverisbed in form to have provided anything more than an indication that pyramids were appropriate to Holy Land settings. There were, and are, pyramids outside Jerusalem in the Kidron Valley a the so-called Tombs of Zechariah and Absalom. The latter has a conical, rather than pyramidal, upper section with concave sides, and is only crudely represented in Reuwich's print, whereas the other is onvitted. Neither is close to Car. paccio's structure, as their pyramidal upper parts are supported on bases articulated with pilaster strips, whereas Carpaccio's pyramid rises straight out of the ground.

a For Filarete's pyramid, we J.M. Huskinson. The Crusifixion of St. postulated. In particular, there is the curious pyramid in the background of the Disputation (Fig. 4) which has been related to Reuwich's print and Middle Eastern sources. ${ }^{22}$ In fact, the origins of Carpaccio's pyramid lie closer to home, in a reconstruction of the Meta Romuli.

The ruinous Meta Romuli, or Sepulcrum Romuli, appears in reconstructed form in the Crucifition of Saint Pefer by Filarete in his bronze doors for old St. Peter's of 1440 (Fig. 5)." Its dividing bands broken up into panels and its pedimented doorway correspond significantly with Carpaccio's pyramid. Filarete's pyramid is accompanied by the Mausoleum of Hadrian, which is probably based on a drawing attributed to Cyriacus of Ancona, ${ }^{i+}$ and his reconstruction of the Meta Romuli may well be derived from the same source. Filarete's pyramid has straight sides, but pyramidal forms with curved sides appear in Reuwich's woodcut. ${ }^{15}$ Representations of the Meta Romuli in maps and views of Rome - as in a woodcut in the Peregrina. tiones - frequently show it with curved sides, which seems to have been the usual convention for woodcut artists when representing any triangular form, be it roof or pyramid. "r It is probable, therefore, that Carpaccio either had access to a version of Filarete's or Cyriacus's reconstruction (Fig. 6) ${ }^{17}$ in which the sides were curved, or that he added the curve himself as a natural property of pyramids.

The adjacent equestrian statue supported on three massive cylinders, articulated by two tiers of niches inhabited by figure sculpture, has no obvious prototype, although it has similarities to the Colleoni monument, which also has a high base divided by three vertical forms. "Possibly it derives from the same source as the structure to the left in the Ordination (Fig. 7), which also has inhabited niches. Both motifs may be fantastic creations by Carpaccio, al-

Peter: A Fifteenth-Century Topographical Problem, Joumal of the War. burg and Courtasid lnstitutes, $x \times 11,1969,135-61$.

"B. Ashmole, "Cyriac of Ancona," Procendings of the British Academy, XLV, 7959, 25

is See $n, 12$ above. A pyramid with concave sides is found in Flarete's treatise, where it crowns one of the pavilions of the ideal city of Plusia. polis, It resembles the Meta Romult in that the apex flares out to form a platform supporting a trumpeting putto and there are doors in the base. (fig. 6). The crockets roughly correspond with the volutes on the hori. zontal bands of Carpaccio's pyramid. There are also links with the Arce Foscari in Venice. See Filarete's Troztise on Architecture, trans. I, R. Spencer. New Haven and London, 1962, 11, fol. 122r, and D. Pincus. The Arco Foscari. the Building of a Triumplial Gateusy in Fiftomth Century Verice, New York and London, 1976, 125, n. 19.

1* Another example is an anonymous miniature of the first quarter of the 15th century, repr. in A.P. Frutaz, Le piante di Rama, Rome, 1962. pl. 150 .

17 Both Mantegrna and Gentile Bellini drew on a manuscript of Cyriacus in the years around 1500 . which Carpaccio could therefore have known. See P.W. Lehmann. Cyriacus of Ancona's Egyntian Visit and Its Reflections in Gentile Bellini and Hieronymus Bosch, Locust Valley, NY, 1977. passim.

14 Cf. Fiocco, 46, who also mentions the Gattamelata: Muraro (Carpaccio, Florence 1966, cxcrvi) relates it to the Arch of the Scaligeri at Werona. Neither of these, however, are supported on freestanding columns of piers. 
1 Carpaccio, The Sermon of Saint Stephen.

Paris, Louvre (photo:

Reunion des Mustibes

Nationaux]

2 Carpaccio, The Stoning of Saint Stephen.

Stutteart, Staatspalerie (photo: Staatsgalerie) 


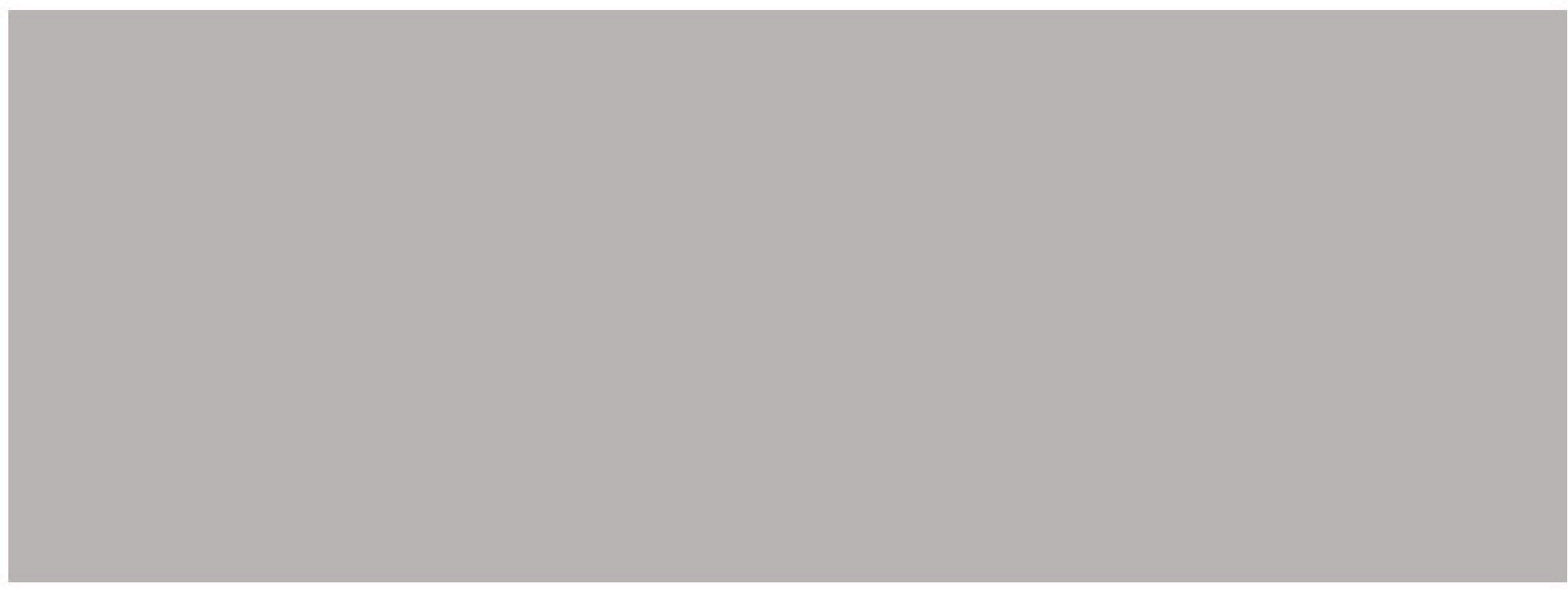

3 Erhard Reuwich, View of Jerusalem, from Breydenbach, Peregrinationes in Terram Sanctam

though it is more probable that they are derived more or less intact from an unknown source, for Carpaccio's fantasy generally lies in the combination of complete units. Either way, these structures have Renaissance or antique, rather than Oriental, origins.

The remaining elements of the settings of these paintings can be traced to Western sources. In the Ordination the building behind Saint Peter can be related to Venetian types, and the minaret, although clearly Oriental, probably came at second hand from Gentile Bellini, who used such towers in his Saint Mark Addressing the Alexandrians, ${ }^{10}$ The wall beyond has characteristically Venetian chimneys, and the castle is a north Italian type exemplified by the castle of Soncino (Cremona). Although the effect of this sequence of structures is of a unified whole, it has been achieved solely by their juxtaposition, without any attempt to join them convincingly. For example, although the main orthogonals of the wall of the foreground structure are continued by the wall beyond, an examination of the ground lines reveals that the latter wall is set back. It in turn is not attached to the castle beyond, for the entrance to the castle goes behind the unbroken vertical of the end of the wall. and the two units have different vanishing points.

In the Disputation the receding city wall lined with tow-

\footnotetext{
"Milan, Brera. No. 164. On Gentile's sources for this painting, see Lehmann $\langle a s$ in $n .17$.

a V. Goloabew, Les dessins de lacopo Bellini, Brussels, 1912, 1, fols. 1b and $2 \mathrm{a}$.

${ }^{11}$ H. Eqzer, Coujex Escurialensis, ein Skizzenbuch aus der Werkstatt Domerico Gkiriandaios, Vienna, 1905-06. fols. $15 v$ and 24.

${ }^{2}$ C.C. Vermeule. "The Dal Pozzo-Albani Drawings of Classical Antiquities in the British Museum." Transactions of the American Philosophicul Society. 1, 5, 1960. No. 380, fig. 87

IJ T. Ashby, "Sixteenth-Century Drawings of Roman Buildingss Attributed to Andreas Coner." Papers of the British School at Rome, 1n, 1904, No. 139. fols. 21, 68-69.

24 R. Weiss, The Rmaissance Discovery of Classical Antiquity. Onford. 1969, 138, 146 .
}

ers is a Venetian motif that occurs in Jacopo Bellini's sketchbook, ${ }^{n}$ and it is combined with a Gentilesque minaret. The architecture of the loggia, with its columns on high pedestals, recalls the ground-floor androni of Venetian scuole, while the conspicuous drums and simple flat acanthus leaves of the capitals are often met with in Venetian painting. The swags that hang from the rosettes, like the pyramid, reflect Carpaccio's awareness of the stream of Renaissance thought concerned with the archaeological discovery of antiquity, as related capitals can be found in sketchbooks devoted to antique remains. In the Codex Escurialensis is a capital with swags running beneath the volutes (although they begin low down at the feet of an eagle), and a few sheets later is a capital where the swags hang from cornucopias, ${ }^{2 t}$ a type used by Mantegna in his Circumcision in the Uffizi. The Dal Pozzo-Albani drawings include one of a Corinthian capital with swags beginning at the rosettes," while the Andreas Coner sketchbook contains a similar, Composite capital, 2 Other archacological motifs are found in the Sermon. The triumphal arch interpolated into the view of Jerusalem is based on the Arch of Trajan at Ancona, which was popular among antiquaries for its inscription. ${ }^{24}$ It is found in the Codex Escurialensis, ${ }^{25}$ although Carpaccio may have seen it for himself., ${ }^{\text {th }}$

\footnotetext{
25 Egyer (as in n. 21.], fol. 27. This derivation, proposed by Zampetti, 518 , is confirmed by the arrangement of projections and recessions (which Carpaccio has rendered more accurately than the artist of the Codex Es. curialensis), the vertical proportions, and by the pairs of figures on each side which correspond to the tablets in the arch. The Arch of Titus in Rome is of a similar type, but its fragmentary state during, the Renaissance. as well as its squatter proportions, make any connection improbable. Fioceo, 46, suggests unconvincingly the Arch of Augustus at Rimini.

4. Zampetti. 517-18, has sugesested that the drawing in the British Museum (n. 1897-4-10-1) inscribed "Porto d'Ancona ..." was sketched from life, but this is unlikely in view of the improbable and highly conventional overhanging cliff and the presence of undoubted borrowings from Reuwich, which indicate its true nature as a sketch in which compositional ideas are being explored.
} 
4 Carpaccio, The Disputation of Saint

Stephert. Milan, Brera (photo: Brera)

5 Filarete, pyramid from the Crucifixion of Solnt Peter. Vatican, St.

Peter's, bronze doors (photo: author)

6 Pasilion of the Palace of the Ideal City of Phesiepolis, from Filarete's Treatise, Florence, Biblioteca Nacionale (photoc Bibl. Naz.) 


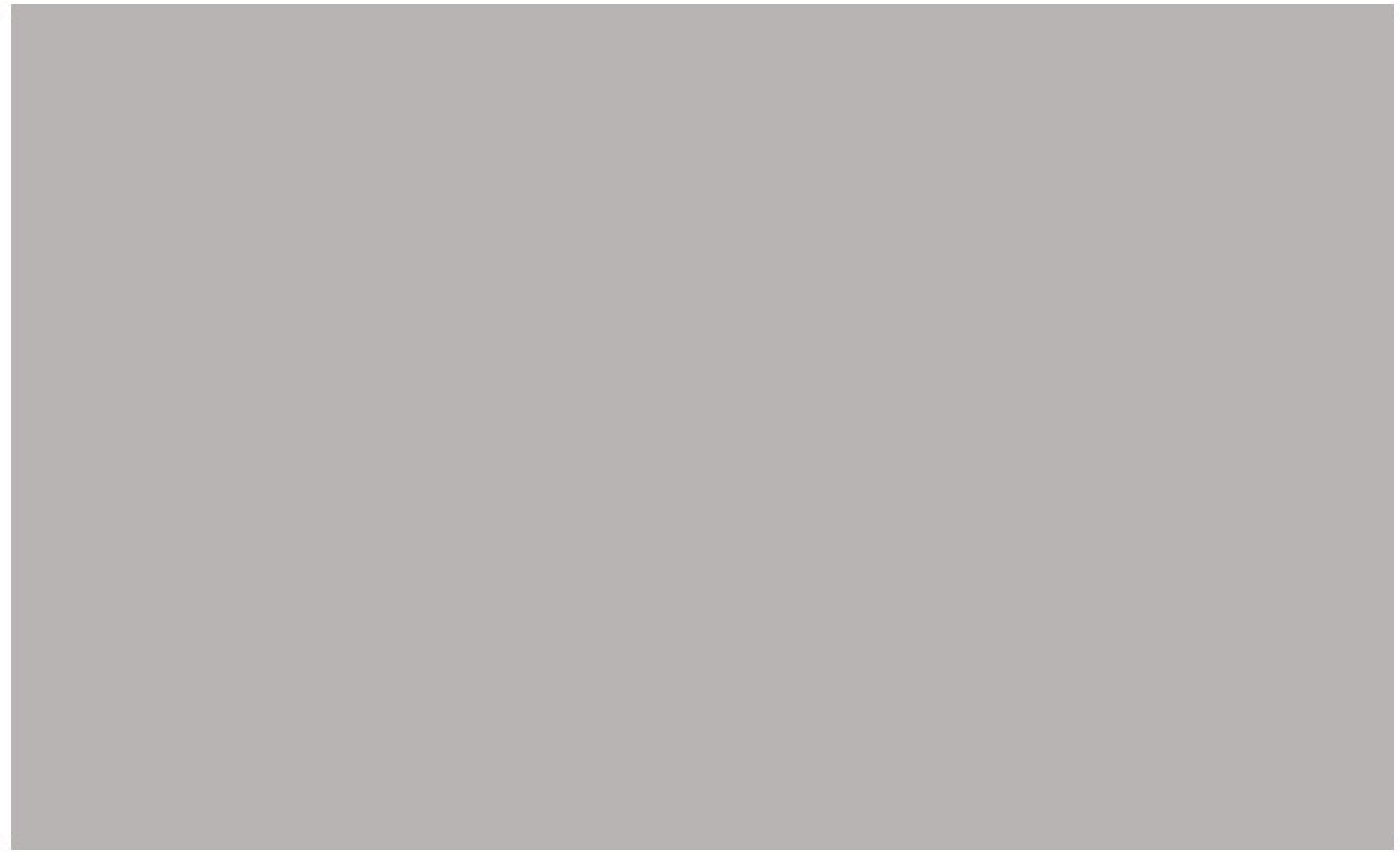

7 Carpaccio, Saint Stephen and His Six Comparions Ondained Dewcon. Berlin-Dahlem, Staatliche Museen (photo: Staatliche Museen zu Berlin?

The head in profile surrounded by a garland that decorates the statue base upon which Saint Stephen is standing is probably derived from ancient coins - the adaptation of coin portraits to architectural settings was a practice that can be traced back through Mantegna to Jacopo Bellinip - although similarly ornamented panels and altar reliefs can be found in sketchbooks.".

\section{II}

A somewhat different problem concerning Carpaccio's use of Reuwich's woodcut is presented by their differing renderings of the site of the saint's martyrdom. Whereas at first glance it seems that Reuwich located the martyrdom within the walls of Jerusalem, Carpaccio in his Stoning of Saint Stephen, in spite of drawing on the woodcut, locates the site unequivocally outside them. ${ }^{\star}$ In doing so Carpaccio followed the explicit biblical, ${ }^{30}$ hagiographical, pilgrim, and pictorial traditions. ${ }^{31}$ In the pilgrim traditions two sites had been proposed. ${ }^{12}$ According to an early tradition, the site lay outside the north gate," but during the twelfth century one outside the east gate was identified. By the end of the fifteenth century the eastern site had become the z P.D. Knabenshue, "Ancient and Mediaeval Elements in Mantegna's Trial of Saint James," Art Bulletin, xL, 1959, 60.

${ }^{20}$ E.g., C. Hulsen, Das Skizzenbucît des Giovarnantonio Dosio, Berlin. 1933, pl. cxxvur.

$n \mathrm{CF}$. Ludwig and Molmenti. 187! "Reuwich's large panoramic view of Jerusalem shows at the extremity of the drawing - but within the cily walls - the 'spot where St. Stephen was stoned' lubi sanctus stephanus fuit lapidatus\}. Carpaccio copies this part of the city exactly but following the Golden Legend places the scene of the martyrdom as outside the wall. ..."

${ }^{30}$ Acts 6: 57-58: "When they cried out with a loud voice, and stopped their ears, and ran upon him with one accord, and cast him out of the city, and stoned him"; The Golden Lezend Erglished by William Caxton. London, 1900, 154.
Is Giulio Romane's Marryrdom of Saint Stepdan (Genoa, Sto. Stefano) is exceptional in that there are no obvious walls or gates, but only a series of disconnected Roman ruins. Significantly, an engraving by Domenico del Barbiere $1 \mathrm{H}$. Zerner, The School of Fontainebines, Loodon, 1962, DB2), which seens to be derived from Giulio's composition, restores the gateway.

32 The following account is based on $\mathrm{H}$. Leclerq, 5.v. "Etienne (Martyre et Stpulture de 5aint), Dictionnaire diarchéalogic chrétienne ef de liturgic, ed. E. Cabrol and H. Leclerq, Paris, 1908, and Vincent and Abel. 743.65.

30 This first appeared after the discovery of Saint Stepher's relics in 413. In the Sth century the Empress Eudoxia built a church on the site dedicated to the saint, which was ruined by the Persians in 614 and coenpletely destroyed in 1187 . 


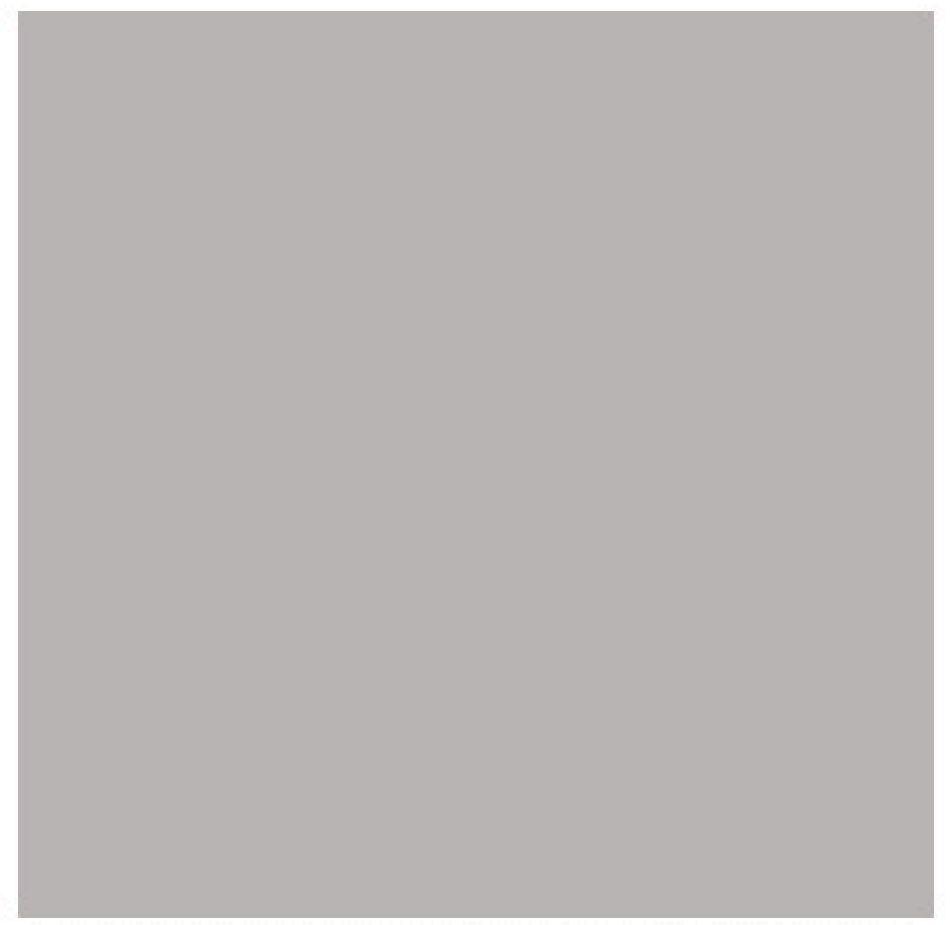

8 Jenusalem from the Mount of Oliess, from Sandys, Relation of a Joumey, ... 190

dominant but not exclusive tradition, and there were occasional attempts to reconcile the two."

One would therefore expect Reuwich to locate the martyrdom at the eastern site. In the pilgrim accounts the site of the martyrdom is normally closely associated with several other sites in a fixed itinerary. These sites include the eastern gate, which was consequently known as St. Stephen's Gate, the Golden Gate, the Torrens Cedron and its bridge, and the Sepulchre of the Virgin on the other side of the stream. Their relationship is clearly shown in an illustration from George Sandys' Relation of a Journey begun An. Dom. 1610, when the situation was little changed (Fig. 8), Surprisingly, Reuwich does not indicate the whereabouts of St. Stephen's Gate, and the other sites are far away. But if one takes another set of topographical in-

is See $\mathrm{n} .39$. There is only one tradition that could be interpected to mean that the martyrdoen took place within the walls. After the destruction of Eudoxia's basilica, the cult of Saint Stephen was removed to the church on Mt. Sion, where pilgrims usally had pointed out to them the sepulchre in which his relics had been placed, along with those of David and the Kings of Judah. As well, there were the stones with which be was stoned Le g. Antoninus Piacentinus, Itinerarium in P. Ceyer, ed., Itinera Hierosolymitana saeculi WL-VII] [Corpus Scriptonem Ecclesiasticonom Latinorum, $\times \times \times 1 \times$ ]. Viesna, 1898, 176, para. 25), which in sone accounts become the stone upon tedach he was stoned. Although it is usually made clear that the stone has been brought from the site of the martyrdom outside the walls, in one case, by an understandable shift of meaning, the site itself sems to be located within the church. In the 9th century the monk Bernard wrote that "juxta quam (ecclesia in monte Syon) versus orientem est exclesia in hosore sancti Stephand, in quo loco lapidatus esse asseritur (Leclerq, as in n. 32, 655-56). Mt. Sion was at this date within the city walls, although atter the 11th century it lay without. But it is not possible that Reuwich was referring to this slender tradition, for Mt. Sion lies on the other side of the city from his inscription. dications - the line of the street that led to the eastern gate and the Church of St. Anne (Domus Sancte Anne) a little to the north of it - it becomes clear that the traditional eastern site is indeed intended.

It follows that one is mistaken in supposing that Reuwich placed the site outside the walls. The feature that most gives this impression is the sweeping curve that includes the site and runs around the northern part of the city. If not the walls, what does this curve represent? And why is the Gate of St. Stephen not represented and the site of the martyrdom not placed close to those sites with which it was usually associated? By examining Reuwich's woodcut in light of its sources and other information available about the topography of the area around the side, it is possible to answer these questions, while at the same time confirming Carpaccio's dependence on the woodcut.

It was usual for maps of Jerusalem to be based on earlier maps, and Reuwich's view continues this tradition. Reuwich seems to have consulted a city plan illustrating Ptolemy's Geography that is conserved in manuscripts in Paris (Fig. 9) and the Vatican (Fig. 10)." This is apparent from the fact that both contain the motif of a U-shaped bend in the Torrens Cedron at the point where it is crossed by the bridge, which encloses the Sepulche of the Virgin Mary. This doubling back of the stream is contrary to topographical reality: the stream continued to the right, past the northeast corner of the city and diverging from it. In the Ptolemy plans the placing of this motif relative to the Golden Gate and the Gate of St. Stephen is reasonably convincing and similar to Sandys' illustration. Reuwich, however, places it well to the left of the Golden Gate in order to make room for the towns of Gabaon and Sylo (Shiloh). and so breaks the connection with the site of Stephen's martyrdom.

In the Ptolemy plans St. Stepher's Gate is clearly marked, so that Reuwich could hardly have been unaware of its existence and position. Had he merely failed to observe the gate, one might have expected him to have substituted a conventional gate like those in the Ptolemy plans: that he did not do so suggests that this section of the wall in fact

IS G. Sandys, Relation of a loweney begun An. Dom, 1670. Foure Bookes, Containing a Description of the Twakigh Empire, of Egypt, of the Holy Land, of the Remote Parts of Italy, and llands adioyming. London, 1615. 190. Sandys' plates of the Holy Land are derived from those in J. Zuallart, Il devotissimo odaggio di Gerusalemime, fatto, e descritto in sed Wibri.... Rome, 1595. ISee R. B. Davies, George Sandys: Poet-Adventurer, London, 1955,71, n. 11 .

36 Paris, Bibl. Nat., Ms Lat. 4802, fol. 135; Vatican, Cod. Urb. Lat. 277. fol. 132\%, dated 1472. The artist or composer of both manuscripts was Piero del Massuio \{1424-1473-80) who would have copied the plans from entlier sources. See G. Scaglia, "The Design of an Archaeological Plan of Rome by Alessandro Strozz, " Jowrnal of the Warburg and Courtancld lnstitutes, rrvu, 1964, 138, n. 4, with bibliog. R. Oehme, "Die Palistinakarte aus Bernhard won Breydenbachs Reise in das Heilige Land 1486," Zentralblatt for Bibliotheksuesen, Lxxy, 1950, 70-85, and R. Röhricht, "Die Palastinakarte Bernhard won Breitenbachs," Zeitscheift des deutschen Palastina-Verwins, xxav, 1901, 1929-35, discuss the relationships of the woodcut with earlier maps of the Holy Land without devoting much attention to the view of Jerusalem or considering the Ptolemy plans. 
9 Jensalem. Paris, Bibl. Nat. ms Lat, 4902, fol, 135 (photo: Bibl. Nat.)

10 Jencsalem, Rome, Bibl. Vat. cod. Urb. Lat. 277, fol. 132v (photo: Bibl. Vat.)

looked not unlike his representation of it.

The gate as it appears today, to which Sandys' rendering approximates, dates from 1537 when the reconstruction of the walls carried out by Suleiman the Magnificent was under way. Its condition during the later fifteenth century seems to have been less substantial. Amold von Harff, who made a pilgrimage in $1498-99$, was not very impressed, saying that it was "made only of wood hanging on wooden posts, like all the gates of Jerusalem." 3 Felix Faber, who wrote the longest and most freshly observed pilgrim account of the fifteenth century, and who accompanied Breydenbach on one of his two pilgrimages, ignores it completely, although he does refer to the site of the martyrdom. The roundabout route that he took to visit the site suggests that the gate was temporarily inaccessible, at least to Christians. This is borne out by a passage that forms part of a description of a circumvallation of the city, where Faber describes having to descend immediately into the Jehoshaphat (or Kidron) Valley from the northeastern corner, and of being unable to follow the path along the foot of the walls because of the Moslem tombs in the vi-

${ }^{27}$ H.G. Mitchell, "The Modern Wall of Jerusslem," Arrual of the American School of Oriental Research in Jerusalem, 1, 1919-20, 38.

20 The Pilgrimage of Amold wor Harff. Kright. from Cologne, through thaly. Syria Esypt, Arabia, Fthropia, Nubia, Palestine, Turkay, France and Spain in the Yaars 1096 to 1499 (Hakluyt Society, 2nd ser., xcrv), trans. and ed. M. Letts, London, 1946, 212.

* The Wanderings of Folix Fabri, trans. A. Stewart, 2 parts in 4 wols. (Palestime Pilgrims Text Society, va-xi, i, 458-461 (fol, IALA-142A). "After we had seen that cistern [the pool of Bethesda] we went on our way, and came to the end of the city on the north side at the gate which once was called the Gate of Ephraim, because the way to Mount Ephraim leads through it; but now it is called the Gate of St. Stephen, because he was led out of it and stoned in the valley beyond it. Throagh this gate leads the road to Sichem, Samaria, and Galilee. So we went out of this pate, and as soon as we were outside, we left the northern roads along which the gate looks, and turned asside to the eastward towards Mocant Olivet. having the holy city on our right hands as we walked. When we came to the corner of the wall where the northern wall foins the eastern one, we turned our faces away from the east, and looked along the wall to the south, where we saw another great city gate on the east side, whose lofty tower has been thrown down and ruined. This gate is termed the Golden Gate. ...

Passing quickly by the Golden Gate, we came down a stecp, rough and stony path to a place where stands a stone, the top whereof is flat. ...

So Saul sat upon the clothes upon this stone, raging against Stephen and blaspheming Christ. ...

From thence we went down a little lower, towards the brook Cedron. and came to the place where Stephen was stoned. ..." Faber's account is confusing because he calls the north gate the Gate of $5 \mathrm{t}$. Stephen. He was familiar with earlier pilgrim accounts (see H.F.M. Prescott, lerusalem Joumey: Pilgrimage to the Holy Land in the Fiftonth Century, London, 1954) and is here probubly sttempting to reconcile the earlier tradition with the later. He would hardly have done so had the eastern gate been passable and clearly the gate associated with the martyriom. 


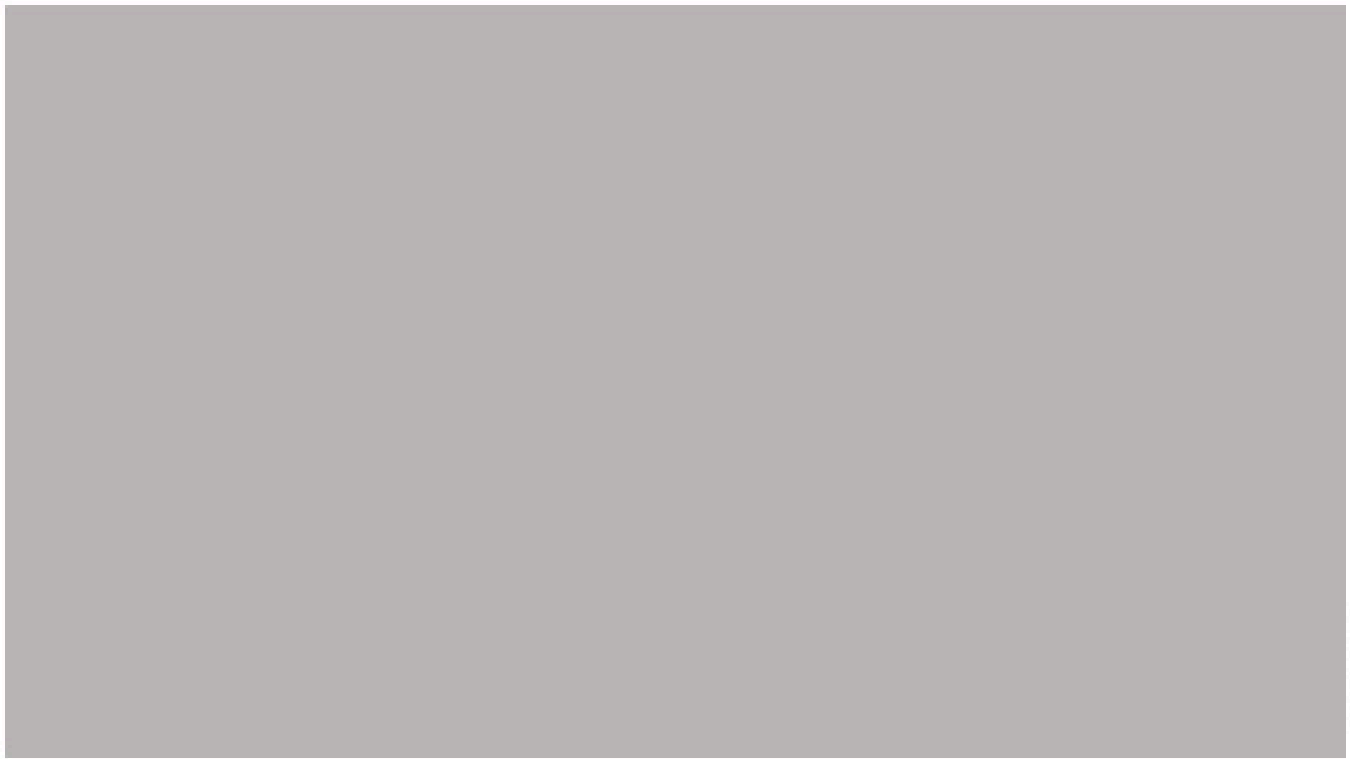

11 Scorel, The Entry of Christ into Jerusalem, central panel of Lochorst Triptych (detail). Utrecht, Centraal Museum (photo: Centraal Muscum)

cinity of the Golden Gate. ${ }^{48}$

From the Ptolemy plans little can be concluded other than that an opening existed in this position." The most informative representation of the gate before its rebuilding is provided by Jan van Scorel in the view of Jerusalem that occupies the background of the Entry of Christ into Jerusalem, the central panel of the Lochorst Triptych of 152729 (Fig. 11). Scorel went to Jerusalem in 1520-21, and according to Van Mander made sketches there from life.ta This picture seems to be generally reliable, and a marked improvement over Reuwich in the shape of the Dome of the Rock and in the handling of perspective. Scorel represents St. Stephen's Gate as a ruinous, but substantial structure. Seen from Scorel's viewpoint on the Mt. of Olives, the gate is relatively conspicuous, but seen from lower down and at any angle other than frontally, it would have been hidden from sight by the projecting walls.

Although the primary inspiration for Reuwich's view is also the view from the Mt. of Olives, his work is not a single unified impression like Scorel's. His Church of the Holy Sepulchre, for example, is seen from the south rather than the east because it is a simplification of the view from the forecourt used for the separate woodcut devoted to the church alone. The view of the city as a whole, too, is oriented differently from the map of the Holy Land that surrounds it; it is seen from the east, whereas the map is seen from the west. Similarly, his representation of the area around the gate (Fig. 12) seems to have been taken from a different position so that it presents a different appearance from that in Scorel's view. But if each form is studied closely, most of the features near the site of the martyrdom can be identified with reasonable certainty.

The words "Locus ubi Sanctus Stephanus fuit lapidatus" are placed beneath an undulating line which clearly represents a hill, near parallel lines that meander back and forth, clearly representing a stream that goes behind the hill. The cross marking the site of Stephen's martyrdom is therefore on the side of the stream closest to the town. Immediately above the cross are two undulating lines representing landscape forms, and above this is a rectangular form without markings: this, I would suggest, represents the city walls. The form overlaps another more or less rectangular form which has what can be identified as a vestigial doorway: this is St. Stephen's Gate. Other sections of wall and buildings correspond to the ruinous northeastern section of the wall, where buildings interrupted, and were built into, the wall. ${ }^{43}$ Going the other way from the cross, there are two buildings with windows in front of a tree, probably the building in front of the wall visible in Scorel's painting immediately to the left of the gate. In front of this is a cubical form surrounded by vegetation which may represent a Moslem tomb, similar to those vis-
40 Faber (as in n. 39.), 1n, 119 (fol. 226). He also laments that the Palm Sunday processions do not dare go beyond the Cedron river for fear of the Saracens: $1_{f} 461$ (fol. 142A).

4. The Paris version represents it as a plain round-arched opening in the wall articulated with lines representing courses of stonework. The degree to which this representation is conventionalized may be gauged by comparing the adjacent Golden Gate with Reuwich's version. In the Vatican version both gateways have been developed with stepped battlements.

42 See Utrucht, Centraal Museum, Jan zan Scord, wh. cat., 1955, Cat. No. n; Douai, Muste de la Chartreuse, Jan van Scorel d'Utrecht, exh. cat, 1977, Cat. No. 18, 79-84. Also reproduced is the woodcut by Herman van Borculo(? derived from Scorel's painting for from his preliminary studies) of 1538 (Cat. No. 39, 85). See also D.H. de Jonge, "Het Triptiek der Familie van Lochorst door lan van Scorel in het Central Museum te Utrecht," Oted-Holland, Lve, 1929.

4 The walls of the enclosure of the Dome of the Rock had been recon. structed in the 14th century, but for political reasons the rest had been allowed to decay (see Vincent and Abel, gazff). When, in the 19th century, a shaft was sunk at the first angle north of St. Stephen's Gate, no traces of "any foundations more ancient than the present city wall, as seen above eround" were found. ISir C. Warren and C.R. Conder. The Surpey of Western Palpstine: Jerisalom, London, 1894, 137). 
ible beneath the middle of the inscription referring to the Golden Gate.44

In short, the cross is certainly outside the wall, between it and the stream, the Torrens Cedron, and in its correct position outside the Gate of St. Stephen. Reuwich has located the martyrdom site in precisely the place where the dominant tradition of the day maintained it should be. The sweeping curve that seems to enclose it within the city boundaries, although superficially resembling a wall, does not join the wall of the enclosure of the Dome of the Rock and lies outside the village of Bethoron Superior, which was many miles away.

The origin of this form can again be traced to the Ptolemy plans. In the Vatican version there is a stream that runs along the north wall of the city, veering south beyond the northeastern corner. This is probably meant to represent the excavation, or dry moat, which lay outside the north wall, and which is visible in Bernardo Amico's view of Jerusalem. ${ }^{4}$ In the Paris version it loses its stream-like and moat-like properties and becomes the outer boundary of an area of hill forms which encloses an octagonal wel] and the village of Emmaus. It is only a step from here to Reuwich's purely conventional line enclosing the village of Bethoron Superior, the purpose of which is to separate the view of the city from the map of the Holy Land beyond.

Although Carpaccio has not followed Reuwich's representation of the walls and gate, it is nevertheless tempting to suppose that he took up the suggestion of a sweeping curved wall that this line suggests. We can imagine him faced with the task of creating a suitable setting for his subject, beginning by consulting Reuwich's woodcut, which would have been the most accurate source of information available to him. Although many of the forms - particularly those on the horizon - are fantastic and unlike anything in Reuwich, to there are a number of similarities to the northern part of the city that suggest this was the case. These include the semicircular shape, the bird's-eye view, and the mountainous landscape dotted with villages. One of the most prominent details within the city is an archway, which corresponds to the Ecce Homo arch in the woodcut ("Arcus super quo Christus fuit indicatus"). The road meandering down to the gate can also be found in the woodcut, although the prominent building with nave and aisles cannot. In position it corresponds to the House of Pilate (Domus Pilati), which is what it must be meant to represent.

At this point, Carpaccio would have realized that two items essential to the iconography were lacking. The first is that symbol of Jerusalem which occurs in so many paintings of the Renaissance: a polygonal, two-stage building derived from the Dome of the Rock. This building is found

4 Scorel does not represent this, but Van Borculo represents an open rectangular box to the south of the gate, and a flat slab to the north, both of which are probably tombs. This supports the hypothesis that Van Borculo had access to preliminary drawings and siketches by Scored in which these items appeared, but which Scorel onitted in favor of figure groups.

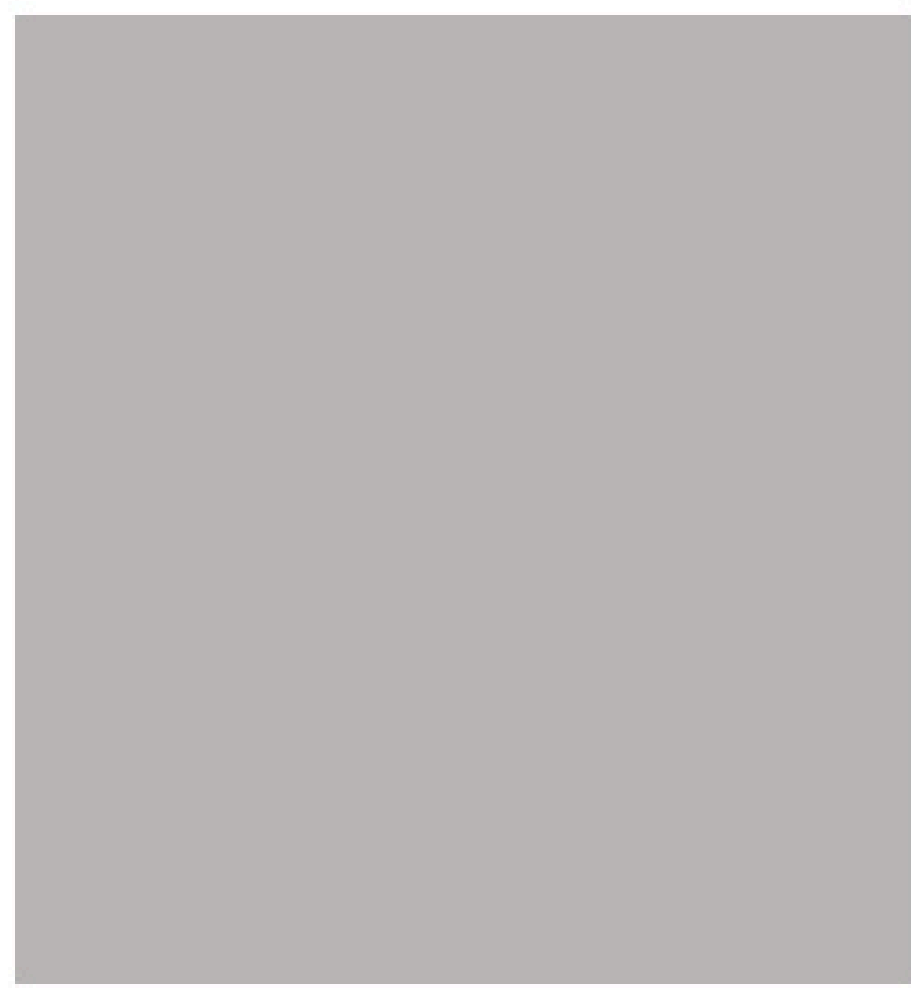

12 Erhard Reuwich, View of Jenesalem, detail of north end

in the woodcut, to be sure, but the choice of the northern end meant that it had been eliminated, and so it was replaced in schematic form to the right of the center of the part of the city shown in the painting. The other essential item is the wall of the city, pierced by a gate. Finding Reuwich's representation inadequate for his purpose, or knowing that he had represented it in its modern, ruined state and not as it had been in antiquity, Carpaccio reconstructed it on the sweeping curve suggested by Reuwich's dividing line, adding in the correct position the Gate of St. Stephen. Certainly the wall and gate have the kind of minimal form one might expect from such a procedure.

\section{III}

There seems, then, to be little reason to suppose that Carpaccio derived any information about Jerusalem that has any topographical validity from any source other than Reuwich. Some motifs that appear at first glance to be Oriental and not found in Reuwich or Breydenbach turn out to be based on Italian or antique prototypes, and sometimes, even though the opposite is indicated, Carpaccio reveals a surprising awareness of the woodcuts. The fantasy and Oriental exoticism which are sometimes detected in these works is the consequence not so much of Eastern influences, or of a fantastic imagination, as of sometimes

45 Bernardo Amico, Trattato delle piente et imaghei dei sacri edifici dil Terrosanta, Rome, 1609, trans. Fr. T. Bellorini and E. Hoade as Sacrent Edifices of the Holy Land, Jerusalem, 1953, chap, xarv, with plate engraved by Callot; alse Sandys tas in n. 35), 158 .

4s The painting was executed largely by assistants; see Lauts, Cat. No. 29. 
rather naive juxtapositions of motifs derived from disparate sources, Carpaccio was essentially a literal-minded artist, and when he confined himself to a unified setting that he knew well, like that in the Accademia Miracle of the Reliquary of the True Cross, this is apparent; but when confronted with the task of recreating a country he had probably never seen, his prosaic method of juxtaposing appropriate motifs created an impression of Oriental fantasy that was never intended.

This literal-minded approach suggests that the two lost views of Jerusalem that were the subject of a letter of August 15, 1511 from Carpaccio to Marchese Gian Francesco Gonzaga were simply copied from Reuwich. Had any other source been used, traces would have appeared in the Saint Stephen paintings, done at intervals during the rest of the decade. The dimensions that Carpaccio supplies for the larger of the two works strongly supports this view: it was $51 / 2 \times 25$ piedi $(1.90 \times 8.57 \mathrm{~m})$, which gives a ratio of height to width of $1: 4.5$. Reuwich's woodcut has almost exactly the same proportions: it is $0.27 \times 1.27 \mathrm{~m}$ or $1: 4.7$, $^{*}$ The unusually elongated nature of these proportions makes it unlikely that their similarity is a coincidence. The smaller

* Muraro, 1966 (as in n. 18), 63-70, who publishes the lester in full with a detailed commentary, suggests that these dimensions refer not to the picture itself but to the dimensions of the Holy Sepulchre in Jerusalem. or to the "rapporti proporzionali fra i vari edifici efluoght depoutati," and that this work was not "una generica Veduta di Gerusalemime ma una raffigurazione di quella citta che doveva avere coene fulcro a Supolicro di Cristo." The wording of the letter is. however, quite explicits "La longeza work Carpaccio described as being not even a tenth of the whole, a fraction that accurately describes the extent of the view utilized in the Sermon (from the Dome of the Rock to the northern end of the enclosure).

University of Melbourne Parkville, Victoria 3052, Australia

\section{Bibliography}

De La Tourette, G. LOriente et les peintres de Venise, Paris, 1924.

Fiocco, G. Carparcio, Paris, 1931

Laubs, J., Carpuccio, Paintings and Dratwings, London, 1962.

Luchiz G, and P. Moimenti. The Life and Works of Vitrane Carpaccio, trans. R.H.H. Cust, London, 1907 .

Tietze, H., and E. Tietze-Conrat, The Dhavings of the Venetian Painters, New York. 1944.

Vincent, L.H., and F. M. Abel, Jerusalem, Recherches de topographie, döarchiologie et d'histoire, it, finsalen nouvelle, Paris, 1926.

Zampetti, P., LOriente del Carpacoio," Vonezia o rOriente, fra tardo me: dioevo e rinscinento, ed. A. Pertusi, Venice, 1966, 511.526.

de l'oprà è de piedi 25 , la largeza è de piedi $5 / 2$ cum tute le misure se ricercano in tal cossa." The unusually large size of the picture, which Muraro adduces in support of his hypothesis, may be explained by the fact that it was executed in watercolor on canvas and could be wound onto a roller ('La forma de Topra è de aquarella sopra la tella, et el se potria voltar sopra un ruodolo sencia alcun detrimento"): it was therefore more a tapestry or processional banner than a rigid painting. 


\section{University Library}

\section{- M M I E E R VA A gateway to Melbourne's research publications}

Minerva Access is the Institutional Repository of The University of Melbourne

Author/s:

Marshall, David R.

Title:

Carpaccio, Saint Stephen, and the topography of Jerusalem

Date:

1984

Citation:

Marshall, D R. (1984). Carpaccio, Saint Stephen, and the topography of Jerusalem. The Art Bulletin, 66(4), 610-620.

Publication Status:

Published

Persistent Link:

http://hdl.handle.net/11343/34942 